\title{
Effects of perceived stakeholder conflict factors on guests' satisfaction and behavioral intentions and mediation effect of guests' perceived value: Evidence from the Hospitality sector of Northern Cyprus
}

\author{
Derya Timucin Hayat ${ }^{a^{*}}$ and Ismet Esenyel ${ }^{\mathrm{a}}$
}

${ }^{a}$ Girne American University - School of Tourism and Hospitality Management. Department of Tourism, Turkey

\begin{tabular}{l}
\hline C H R O N I C L E \\
\hline Article history: \\
Received: June 26, 2020 \\
Received in revised format: \\
June 302020 \\
Accepted: July 26, 2020 \\
Available online: \\
July 26, 2020 \\
\hline Keywords: \\
Conflict \\
Accommodation establishments \\
Tour operators/ travel agencies \\
Guests' perception \\
Scale development \\
Perceived value \\
Guests' satisfaction \\
Behavioral intentions
\end{tabular}

\section{Introduction}

The success of tourism and hospitality businesses and the industry itself requires various actors to provide either primary or supplementary contributions. For this reason, tourism is considered a multidisciplinary industry consisting of many stakeholders such as hoteliers, travel agencies, entrepreneurs, employees, customers, media, and governments (Gananapala, 2016). Hoteliers and tour operators/travel agencies are considered as two major stakeholders in tourism, and they are interdependent with each other with respect to their marketing and service objectives. Johann added that the satisfactory relationship between accommodation facilities and tour operators/travel agencies is a vital issue in terms of providing competitive advantage for both parties in the market; Although these two key stakeholders have long-term business relationships, they have failed to develop successful teamwork (2014), On the contrary, it has been noticed that the relationship between the groups is troubled or even hostile. Most of the existing literature describing stakeholder conflict (a company, and its supplier) as a power of one stakeholder to another, and this kind of description approaching stakeholder conflict as a dual problem (Schul \& Babakus, 1988; Gaski, 1984, Hibbard, Kumar \& Stern, 2001). However, the relationship between organizations in a conflict situation is noticeable by third parties, such as customers, and they may be affected by this deficient business relationship (Mooi \& Frambach, 2009). In recent years, many events of conflict have occurred between accommodation establishments and travel

Few studies have explored the stakeholder conflict from the perspective of hotelier and/or travel agency; however, this study has aimed to investigate stakeholder conflict from the perspective of factor of guests 'perceived value, which has not been examined empirically before. Since no scale unsatisfactory relationship between accommodation establishments and tour operators/travel agencies, this study conceptualized PSCF and developed a scale for assessing this conflict and its outPSCF were identified. Thereafter, the study empirically tested the conceptual model by conducting survey study to collect data. The mediation effects obtained indicated that guests 'perceived value mediated the effects of the PSCF on guest satisfaction and behavioral intentions associated with the reliability. Applying the scale of PSCF enabled the identification of the two consequences of guests' satisfaction and behavioral intentions. Limitations, recommendations for future research and manC 2020 by the authors; licensee Growing Science, Canada 
agencies/ tour operators in North Cyprus. For example, one of the leading tour operators of Turkey engaged in conflict with a local accommodation establishment due to misinformation is provided by the hotel as they were introducing their luxurious rooms, and, all facilities and services available. However, the hotel was under construction with partly finished hotel rooms and improperly operating departments such as a restaurant with few employees, and limited selection of meals. The guests who booked their holidays to this hotel through that particular tour operator were dissatisfied and asking compensation for their ruined holidays. Similarly, one of the five-star hotels, located in Kyrenia, experience conflict with a local travel agency because of its aggressive selling strategies that over-promising related with the hotel facilities and services such as suit room upgrades and free Ala carte menus, however when customers arrive in the hotel and experience the realities they feel frustrated because of over expectations that are developed by the travel agency. Therefore, such situations negatively affect precious stakeholders, "guests" while creating conflict and damaging the relationship between accommodation facilities and tour operators/travel agencies. Despite the fact, there are considerable studies regarding the relationship between tour operators, travel agencies, online tour operators, and hotel industry, the role of stakeholder conflict over another stakeholder (guests) is rarely measured. There are few narratives and empirical studies in the tourism literature that understand the potential source of conflict factors between accommodation establishments and tour operators/travel agencies (Gnanapala, 2016; Mwesiumo \& Halpern, 2016; Ivanov, Stoilova \& Illum, 2015; Kiran, Majumdar \& Kishore, 2012; Buhalis, 2000), perceptions of both parties on conflict factors, dependency on each other and bargaining power (Ivanov et al., 2015) and the effect of the conflict issues on guests' satisfaction (Gnanapala, 2016). None of the research has empirically focused on guests' perceptions of conflict factors between accommodation establishments and tour operators/travel agencies and whether these factors affect the guests' perceived value, satisfaction, and behavioral intention. Kiran et al. (2012) and Buhalis (2000) have been recommended that their findings of the potential sources of conflict occurring in the company's distribution channel and its management can be used as a basis for either qualitative or quantitative further researches. As a result, the study is intended to adopt a third perspective to examine stakeholder conflict, which can broaden our understanding of the driving forces of conflict issues perceived by the guests. In North Cyprus, the construct of study examined recently with different context, like, revisit behaviour intention for Facebook hotel page (Ibrahim \& Aljarah, 2018), also perceived telecommunication service quality-examined with perceived value users' satisfaction (Alrwashdeh et al., 2020). In this article, researchers try to address whether guests are affected by a conflict between accommodation establishments and tour operators/travel agents while remaining outside this business relationship and how they react to the conflict issue.

\section{Literature review}

\subsection{Perceived Stakeholder Conflict Factors (PSCF)}

Accommodation establishments and tour operators/travel agencies are considered as two main stakeholders in the tourism industry, and they are interdependent in terms of their marketing and service objectives. However, it is stated in the existing literature and practically observed that accommodation establishment and tour operators/travel agencies are acting as competitors, and they have failed to develop successful business relationships (Gnanapala, 2016). Since each stakeholder has a different commercial and strategic interest as well as various operational processes; they tend to apply a variety of powerful forces to achieve their goals, usually at the expense of their partners. Therefore, the relationship between various stakeholders is complex and conflict can arise between them (Freeman, 1984). According to the existing literature related to the source of conflict issues between accommodation establishments and tour operators/ travel agencies can be categorized as following headings: Price levels and commissions (Buhalis, 2000; Douglas \& Lubbe, 2006; Ivanov et al., 2015; Mwesiumo \& Halpern, 2016). Contract signing, renewing, negotiation timing and fulfillment of contract obligations (Ivanov et al., 2015; Mwesiumo \& Halpern, 2016), Unrealistic demands (Frazier, 1983; Frazier \& Summersm 1984), Incorrect representations and promotions of the hoteliers' product and services (Ivanov et al., 2015; Gnanapala, 2016), Manipulated results of Customer satisfaction survey and misdirection of tourist in competing accommodation establishments and Tour operators' bankruptcies (Buhalis, 2000), Inconsistency between requested low price by the travel agency and expected quality of the product and services that hotel is expected to offer (Buhalis,2000; Rose \& Shoham, 2004; Ivanov et al., 2015; Gnanapala, 2016), Booking and operational mistakes that result fail to provide necessary service for booking requests and promises (Buhalis, 2000; Ivanov et al., 2015; Gnanapala, 2016) and Overbooking (Ivanov et al., 2015: Gnanapala, 2016), and complaints handling (Gnanapala, 2016). These conflict factors may challenge stakeholders' success and they may also affect customer' outcomes such as guests' satisfaction (Gnanapala, 2016). The reason behind that, some of these disagreements between the parties may be so open that is experienced by the customers, as well as the public, become aware of them (Mwesiumo \& Halpern, 2016). As Freeman (1984, p.46) stated that "stakeholder is any individual or group who can affect or be affected by the achievement of other stakeholders objectives", in view of that stakeholder theory argues that the success of an organization depends on how well it manages its relationship with key interest groups, such as employees, suppliers, customers, communities, financiers, and others that may affect the achievement of its purpose, on the other side, customers, and other interest groups may be affected by unsuccessful buyers and suppliers business relationship. Therefore, a conflict situation between organizations is noticeable, and third parties, such as guests as one of the important stakeholders in the tourism industry may be affected. Based on the statements above, the conflict between accommodation establishments and tour operators/travel agencies, maybe perceived by the guests during their stay at an accommodation establishment and they may spoil their experience and reduce their perceived value and so reduce guests' satisfaction, and behavioral intentions. Therefore, stakeholder conflict is targeted specifically since they include various conflict attributes and form a convenient setting to measure perceived outcomes. The 
Misinformation, Unmanaged booking, and operational mistakes, Quality \& Price Inconsistency and Unsolved guests' problems are identified as PSCF. Misinformation factors referred misrepresentations provided to guests about hotels' services and facilities including misleading promotional materials and overpromised hotel's products and services. Unmanaged Bookings and operational mistakes are related to inconsistency between the requested booking details by the guests, and what is provided by the accommodation establishment including walking the guest to another property. Quality and Price inconsistency referred to the guests' comparison between the prices they paid with their sacrifices, and what they actually experienced related with quality of product and services provided by and employees working in an accommodation establishment. Unsolved Guests' problems referred to both parties' irresponsible manners towards the guests' problems or addressing guests' problems inefficient way. These four conflict factors are considered whether they are experienced by guests whose trip were organized through a tour operators/ travel agency, and staying in five or four-star accommodation establishments located in Kyrenia, North Cyprus and whether overall PSCF is effective on guests' outcomes namely guests' satisfaction and behavioral intentions associated with accommodation establishments while testing the mediating effect of guests' perceived value between PSCF and guests' satisfaction and behavioral intentions.

\subsection{Perceived value}

The perceived value is defined from monetary, quality and benefit perspectives, in this study, benefit perspective has been adopted and it is explained as the assessment of the guests' benefits of a product or service, in exchange for what the guests have to sacrifice for obtaining that product or services. The sacrifice includes non-monetary costs such as cost of the transaction; search, negotiation, and time to spend during the purchase besides the paid amount for the particular goods and/or services (Zeithaml, 1988). Previous studies have pointed out that there is a positive relationship between perceived value and customer satisfaction (Lin \& Wang, 2006; Tung, 2004; cited in Kuo, Wu \& Deng, 2009). Also, many researchers found a direct relationship between word-of-mouth recommendations and guests' perceived value as well as between behavioral intentions and guests' perceived value (Cronin, Brady \& Hult, 2000).

\subsection{Guests' satisfaction}

Guests' satisfaction is explained as a difference between guests' perception of the received services and guests' expectations of the services (Gupta, McDaniel \& Herath, 2005). According to this definition, it can be said that, when a guests' perception of the received service has below their expectations, their satisfaction will be negative or vice versa. Moreover, Moutinho (1987) described satisfaction as a function of the relationship between the expectation during pre-travel and experience during post-travel. If guests cannot meet their travel expectations, they will be dissatisfied. Also, Oliver and Desarbo (1988) highlight that if a tourist's expectations are matched to the actual performance of the product or services, he/she will be satisfied. Gupta et al, (2005) also mentioned the framework for confirmation or disconfirmation which explains that consumers have a set of established criteria in their minds and when to purchase a product or service; customers generally tend to compare the product or service with their criterion. Therefore, because of guests' own criteria, and their comparisons with actual products and services shape their level of satisfaction or dissatisfaction. Moreover, Hu et al. (2009) stated that Customer satisfaction is generally structured as a post-consumption assessment based on the perceived value. Lastly customer satisfaction considered as antecedents affecting brand loyalty (Aljarah \& Ibrahim, 2020)

\subsection{Behavioral Intentions}

The concept of behavioral intent is called people's beliefs about what they want to do in a particular situation (Ajzen \& Fishbein, 1980 cited in $\mathrm{Wu}, 2013)$. Another definition of behavioral intentions refers that the possibility of a customer returning to a company where he/she has used the company's service and/or spreading positive information about the company to family, friends, and colleagues (Olorunniwo, Hsu \& Udo, 2006). Zeithaml, Berry \& Parasuraman (1996) highlighted that behavioral intention can be seen when a customer decides to continue with the company or not. When tourists away from their home can enjoy the facilities and comfort provided by an accommodation establishment and they may attach to the place. On the other hand, when visitors end up with a bad experience related to accommodation' services or facilities, they likely have less intention to return to that place (Ahliya, 2010). Bolton \& Drew (1991) have suggested that customers' behavioral intentions are determined by partially perceived value. From theoretical side theory of reasoned action (TRA) for Fishbein \& Ajzen, 1975, which assumes that behavioral intention leads to actual behavior and this is used to define consumers' attitudes concerning purchasing or using a brand by considering normative values or subjective norms (Ibrahim et al., 2020). The current study empirically explored the relationships shown in the conceptual model (Fig. 1) and was presented in the above five studying hypotheses to establish the relationship between perceived stakeholder conflict factors and guests' satisfaction and behavioral intentions as well as finding the mediating effect of perceived value between the study variables.

\section{The Research Hypotheses}

H1: There is a significant and negative relationship between perceived stakeholder conflict factors and guests' perceived value.

H2: There is a significant and negative relationship between perceived stakeholder conflict factors and guests' satisfaction.

H3: There is a significant and negative relationship between perceived stakeholder conflict factors and guests' behavioral intentions. 
H4: The relationship between perceived stakeholder conflict factors and guests' satisfaction is significantly mediated by guests' perceived value.

H5: The relationship between perceived stakeholder conflict factors and guests' behavioral intentions is significantly mediated by guests' perceived value.

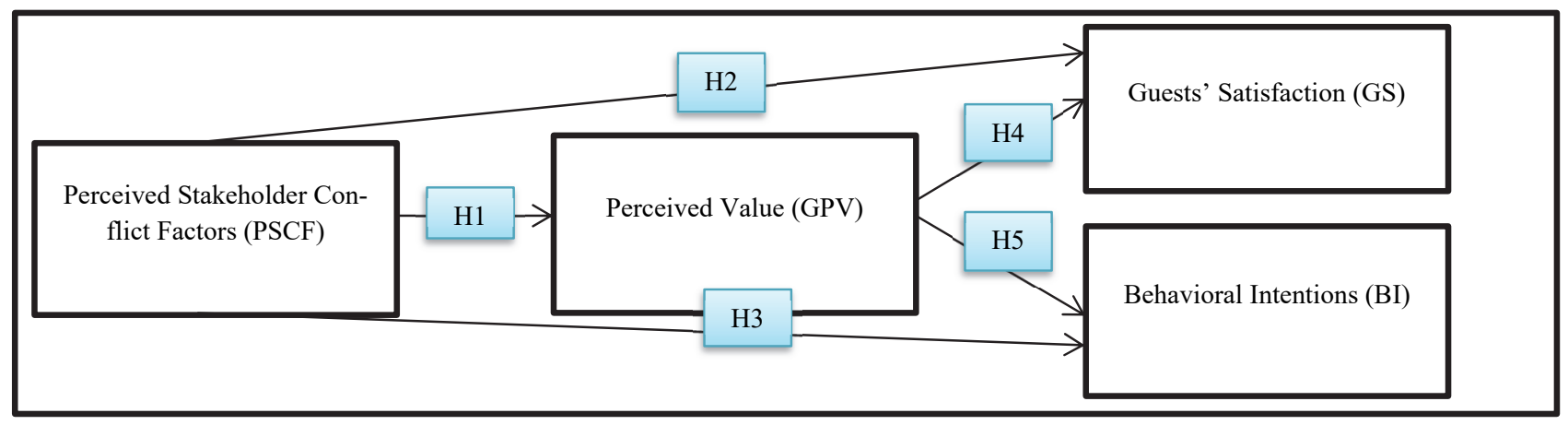

Fig. 1. Research Conceptual Framework

\section{Research Method}

\subsection{Questionnaire design}

A self-administered survey questionnaire is designed and is used to collect the necessary data. The survey questionnaire is consisting of four parts; part (1) includes a cover page that explains the motivation for the research and assures the anonymity of the respondents. Part (2) consists of screening questions to determine whether respondents are eligible to take part in this research. Part (3) of the questionnaire aimed to collect demographic information of the sample. Part (4) consists of items that measure respondents' level of agreement with statements that describe PSCF between accommodation establishments and tour operators/ travel agencies, their satisfaction with the accommodation establishment, and their positive/negative behavioral intentions. Five-point Likert-scale type of questions is used ranging from "Completely Disagree" (1), to "Completely Agree" (5), are used. Five-Point Likert-scale type of questions has been very popular in many previous kinds of research which were investigating experienced value, customer satisfaction, behavioral intentions (Chen, 2007). A high overall score shows a negative attitude, whereas a low overall score represents a positive attitude.

\subsection{Scale construction}

No scale found that measures perceived conflict factors arose from the unsatisfactory relationship between accommodation establishments and tour operators/travel agencies. After carefully reviewing the literature, 15 semi-structured face-to-face interviews undertaken with professional tourism practitioners from accommodation establishments, and travel agencies, afterward, interview narratives were analyzed to identify the dimensions associated with PSCF in hospitality sector which helps to generate a pool of items (Churchill, 1979); by using this method, the researcher generated an initial pool of 22 items to represent PSCF. Following the generation of the initial item, to ensure face and construct/content validity (Netemeyer, Durvasula \& Lichtenstein, 1991), six subject experts in tourism and hospitality studies from different universities in Northern Cyprus were conducted; four subject experts from Girne American University, one subject expert from Cyprus Science University, and one subject expert from Final International University. These six subject expert judges were invited (individually or in a group of two or three) to undertake the evaluation of those 22 items. Items which rated two or below on a five-point scale $(1=$ not relevant, $5=$ very relevant) were eliminated and items which rated three and above were selected regarding their representatives, specificity and clarity of the items (e.g. Haynes, Richard \& Kubany, 1995), and accordingly four items were removed and 18 items remained. Thereafter, 10 guests whose trip were organized by a tour operator/travel agency accessibly selected from two accommodation establishments located in Kyrenia, North Cyprus (one five-star and one four-star) after permission taken from the management of these two accommodation establishments and from the guests whether they were willing to participate. Therefore, two focus groups were created consisting of five guests in each focus group. Cox, Higginbotham \& Burton (1976) suggest that the focus group interview is an effective qualitative technique for use in marketing and management research. Edmunds (1999) recommends using five or six participants when focus group interviews are conducted. The guests evaluated the clarity of the wording of the 18 items, and their suggestions resulted in deletion of an item. Thereby it resulted in reducing the relevant items to 17 items. After all the evaluations of the items, one item remained under the dimension of unmanaged bookings by travel agencies, and instead of deleting this significant dimension, it was combined with two items of operational mistakes and named as "Unmanaged bookings and operational mistakes". It was allowable to combine two dimensions under one dimension because both are considering unmanaged guests' bookings at different stages. Therefore, PSCF were measured by using four (4) main dimensions and 17 items; four (4) items measuring, "Misinformation", three (3) items, "Misinformation", three (3) items measuring "unmanaged bookings and operational mistakes", six items measuring, "inconsistency between price and quality" and four (4) items measuring "unsolved guests' problems ". 
Moreover, three items measuring guests' perceived value, three items measuring guests' satisfaction, and five items measuring behavioral intentions were adopted from previous studies (Ryu, Lee \& Kim, 2012; Ryu, Han \& Kim, 2008). A pilot study was conducted to 43 guests whose trip was organized by a tour operator/travel agency, and staying in 5-star and 4-star accommodation establishments located in Kyrenia, North Cyprus. A pilot study is recommended to improve data collection design and generate more relevant questions for the fieldwork (Creswell, 2012). The pilot test was applied in August 2019. Through conducting a pilot study, the researcher aimed to ensure whether there was any need to eliminate any items because of their low correlation coefficients to the entire scale and whether there was any requirement for minor modifications of wording and data coding.

\subsection{Data Collection and analysis}

A total of 150 registered accommodation establishments were identified from the records of the North Cyprus Tourism Authority, of which 89 are located in Kyrenia. The Kyrenia region is the most popular tourist destination in North Cyprus (Nadiri, 2003), with its touristic attractions such as heritage sites and its beauty fascinating local and international visitors all over the year. Stratified sampling technique was used to choose accommodation establishments to be able to reach targeted key respondents within the limited time scale of data collection, therefore stratification found a use for sorting out those with certain demographic characteristics from the selected small geographic area as concentrations of certain groups with certain characteristics (Proctor, 2005). Through using stratified sampling, 20 accommodation establishments were chosen; 13 five-star hotels and seven four-star hotels located in the central, eastern, and western region of Kyrenia. The study area is represented $22.47 \%$ of the total number of accommodation establishments in Northern Cyprus. Thereafter, participants were selected based on judgmental sampling technique which is defined as "selecting a sample that matches the purposes of the study to obtain typical population elements in the sample" (Ritche, 1994). Accordingly, guests whose trip were organized by a travel agency/tour operator and staying five or four-star accommodation establishments located in Kyrenia were invited to complete a questionnaire. A total of 330 usable questionnaires were collected over a period of five months (September 2019 - January 2020).

\subsection{Assessing the reliability and validity of constructs}

The researchers conducted six subject experts in Tourism and Hospitality studies from different Universities in Northern Cyprus to ensure face and construct validity of the generated items (22) to evaluate and test the items (survey instruments) for clarity, conciseness, and content validity, shortly for rating their relevance to PSCF. Thereafter, a pilot-test was used to technically asses construct validity and reliability of the survey. The analysis of Pilot study and full-scale survey's Cronbach alpha results are very close to each other. In this case, the application of item analysis provided positive results, and remarkably pilot study and full survey Cronbach's alpha are above the extensively recognized rule of an exceeded minimum of 7 which indicates values are adequately reliable (Nunnally, 1978). Table 1, illustrates the Cronbach Alpha of Pilot Study for PSCF and Table 2 presents Cronbach's Alpha of Full-scale survey for PSCF.

Table 1

Cronbach's Alpha for Perceived Stakeholder Conflict Factors -Pilot Study

\begin{tabular}{ccc}
\hline Independent Variables & Number of Item(s) & Cronbach's Alpha (1) \\
\hline Misinformation & 4 & .807 \\
Unmanaged Bookings \& Operational Mistakes & 3 & .801 \\
Quality and Price Inconsistency & 6 & .951 \\
Unsolved Guests Problems & 4 & .811 \\
\hline
\end{tabular}

Table 2

Cronbach's Alpha for Perceived Stakeholder Conflict Factors - Survey

\begin{tabular}{ccc}
\hline Independent Variables & Number of Item(s) & Cronbach's Alpha (2) \\
\hline Misinformation & 4 & .866 \\
Unmanaged Bookings and Operational Mistakes & 3 & .752 \\
Inconsistency between Quality and Price & 6 & .840 \\
Unsolved Guests Problems & 4 & .739 \\
\hline
\end{tabular}

Before the hypotheses of the study are examined, the researchers conducted Collinearity tests (Table 3 ), to ensure there is no high correlation between the independent variables (Multicollinearity) by examining the outcomes of the test variation allowed values, (Tolerance), Variance Inflation Factory (VIF) for each variant of the study's variables and coefficient torsion (Skewness). When the results of (Table 3) are examined, it can be observed that values of VIF for all variables (Misinformation, Unmanaged Bookings, Quality \& Price Inconsistency, and Unsolved Problems) are less than (10) between (2.720 and 5.146). And Tolerance value is a range between $(0.194,0.368)$, which is greater than $(0.05)$ or should not be less than 0.1 and this is an indication of the lack of a high correlation between the independent variables (Multicollinearity). Moreover, values (Skewness) of all variables are less than (1) $(0.520,0.433,0.250$, and 0.320$)$ respectively which shows that the data follow the normal distribution, and data is less skewed. It can be said that multicollinearity is not problematic and shows the reliability of data. 
Table 3

Collinearity Statistics (Skewness, Tolerance, and VIF test)

\begin{tabular}{cccc}
\hline Factors & VIF & Tolerance & Skewness \\
\hline Misinformation & 4.204 & 0.238 & 0.320 \\
Unmanaged Bookings & $\mathbf{3 . 3 2 4}$ & $\mathbf{0 . 3 0 1}$ & $\mathbf{0 . 5 2 0}$ \\
Quality \& Price Inconsistency & 5.146 & 0.194 & 0.250 \\
Unsolved Guests' Problem & $\mathbf{2 . 7 2 0}$ & $\mathbf{0 . 3 6 8}$ & $\mathbf{0 . 4 3 3}$ \\
\hline
\end{tabular}

\section{Results and discussions}

\subsection{Sample demographics}

Regarding the gender and age of the guest participants, this study is consistent with Karatepe \& Ekiz (2004) and Nadiri \& Hussain (2005). As the findings of Karatepe \& Ekiz (2004) indicate that males were the leading group that visited North Cyprus with $62.7 \%$ and $67 \%$ of the respondents were at the age of 38 and 57. The findings of Nadiri \& Hussain (2005) showed males by $58.9 \%$ and age of guests were above 40 were the majority groups who are accommodating in North Cyprus' hotels, while the findings of this study show, the majority group of guests participants in this study was males by $58.2 \%$ and respondents group of age is 55 years old or above. However, this study is inconsistent with Nadiri, Hussain, Haktan \& Erdogan (2008) and Kourosh (2014) regarding gender and age group of the respondents. As the findings of (Nadiri et al., 2008) indicated that $53.5 \%$ of the respondents were female and the majority of the respondents' age group were between 18-27 years old and the findings of Kourosh (2014) indicated that the majority of guests visiting Northern Cyprus were female with the $51 \%$ and $40 \%$ of the guests were within the group of 36-45 years old, followed by the age group of 26-35 years old which constituted at about $39 \%$. Additionally, related with the nationalities of the respondents visiting Northern Cyprus, this study is consistent with Nadiri \& Hussain (2005) as their findings indicated that $48.1 \%$ of the respondents were coming from the United Kingdom and consistent with Kourosh (2014) as his findings showed that $51 \%$ of the guests were Turkish, and the rest was from other countries mostly from the United Kingdom and Iran. While in this study, People from Turkey and the United Kingdom seem to be top visitors to Northern Cyprus as they score $49.1 \%$ and $33.6 \%$ respectively. When the annual income of respondents was examined, it is observed that this study is inconsistent with Kourosh (2014) and the findings showed that income level of the respondents participated in his research between $\$ 1,000$ and $\$ 5,000$ with $78 \%$ and tourists were earning between $\$ 5,000$ and $\$ 10,000$ with $15 \%$, however, according to the findings of this study, the largest group was earning between $\$ 10,001-\$ 20,000$ a year by $46.1 \%$, while the second-largest group was between $\$ 20,001-\$ 35,000$ a year by $31.2 \%$. On the other hand, the current study is consistent with the (Kourosh, 2014) as his findings indicated that the purpose of visiting Northern Cyprus was a vocation with $54 \%$, while in this study, the majority of the respondents visited Northern Cyprus for the purpose of leisure/holiday with $88.5 \%$. Moreover, the study is consistent with (Gnanapal, 2016), as the scholar stated that in developing and undeveloped countries, accommodation establishments mainly receive business through intermediaries, i.e. tour operators and travel agencies, while in this study the majority group of guests was organized their holiday through traditional travel agencies by $77 \%$. Based on the data collected from the descriptive characteristics of the respondents, the majority of the guests involved in the study were traveling to North Cyprus with their spouse, which is ranked about $38.2 \%$. The following guests who are traveling with their family-kids are about $30.6 \%$. Moreover, the data displays that $46.4 \%$ of the respondents have prior experience of the particular accommodation establishments.

\subsection{Results presentations for Research Hypothesis}

\section{Effect of PSCF on Guests' perceived value (Path-a) (H1)}

The result of PSCF's effect on guests' perceived value is presented in Table 4. The coefficient obtained on (path-a) is (-.739) and $\mathrm{p}=0.000(\mathrm{p}<0.05)$, indicates a negative and significant relationship between PSCF and Guests' perceived value. The lower limit confidence interval (LLCI) is (0.6718) and the Upper limit confidence interval (ULCI) is (0.8062) and the LLCI and ULCI values indicate significant effect between PSCF and Guests' perceived value. Therefore, we accept our Hypothesis 1.

The results are consistent with other studies which are indicating that when conflict factors are perceived by guests during their stay at an accommodation establishment, it may spoil their experience and reduce their perceived value in terms of poor quality product and services (Bastakis, Buhalis \& Butler, 2004; Buhalis, 2000), unexpected service failures and inconvenience (Yildirim, Oflas \&Yurt, 2018), consulted misinformation (Dolores, Salvadore, \& Lorenza, 2012), not provided corrective actions or compensations for the experience problems (Goodwin \& Ross, 1992). Moreover, Ghada Abd-Ala, (2007) findings showed that lower quality products and services help to minimize the value chain of the guests ' experience.

\section{Effect of PSCF on Guests' satisfaction (Path-c1) (H2) and on Guests Behavioral Intentions (Path-c2) H3}

As the coefficient obtained on patch-c1 is $(-.8401), \mathrm{p}=0.000(\mathrm{p}<0.05)$, while LLIC and ULCI values are 0.8679 and 1.0123 respectively. The results for (path-c1) indicate a significant effect between PSCF and Guests' satisfaction. In addition, the presented third result in Table 4, shows the patch-c2 coefficient as $-.7872,(-0.8401), \mathrm{p}=0.000(\mathrm{p}<0.05)$, while LLCI and ULCI values are 0.6982 and 0.8763 respectively. The results for (patch-c2) show significant effect along patch-c2, between PSCF and Guests' Behavioral intentions. Hereafter, we accept our Hypothesis 2 and Hypothesis 3. Related with the effect of PSCF on guests' satisfaction, the results are consistent with many studies. The findings of Fountoulaki, Leue and Jung (2014) 
showed that when misinformation is given about facilities and services of an accommodation establishment, it results in dissatisfied and untrusted customers. Likewise, the findings of Ivanov et al., (2015) showed that as failure to report repairs, renovations or any construction work within and / or around the property or non-functioning facilities and non-updated website are just a few of the possible conflict points that may cause tension between the stakeholders and consequently it may disappoint guests. Moreover, the findings of Yildirim, et al., (2018) and Maxham, (2001) showed that when guests perceived, unexpected service failures and inconveniences such as related with poor quality and unhandled booking requests during their stay at accommodation establishments cause dissatisfaction. Similarly, as the findings of Gnanapala (2016) mentioned that when guests get a hotel room that does not match with their requested room view, they may be frustrated and dissatisfied. In terms of the effect of PSCF on guests' behavioral intentions, the study is consistent with studies of Goodwin \& Ross (1992) and Smith, Bolton \& Wagner (1999), as their findings showed that uncovered service failures or guests' complaints may lead to negative behavioral intentions and as the results of Gnanapala (2016)'s study stated that poor service quality may lead negative word of mouth recommendations to their relatives, friends, neighbors, and colleagues.

\section{Table 4}

\begin{tabular}{cccccc}
\multicolumn{6}{c}{ Effect of PSCF on Guests' Perceived Value, Guests' satisfaction and Behavioral Intentions (H1, H2 \& 3) } \\
\hline & coeff & p & LLCI & ULCI & Result \\
\hline H1: PSCF - GPV (Path-a) & -.7390 & .0000 & .6718 & .8062 & Accepted \\
H2: PSCF - GS (Patch c-1) & -.8401 & .0000 & .8679 & 1.0123 & Accepted \\
H3: PSCF - BI (Path-c-2) & -.7872 & .0000 & .6982 & .8763 & Accepted \\
\hline
\end{tabular}

The mediation effect of guest perceived value (Hypothesis 4 \& Hypothesis 5)

This study employed bootstrapping procedures, which assisted the exploration of the guest perceived value as mediator simultaneously in the association between focal independent PSCF and dependent variable (i.e., guest satisfaction and behavior intention) (Preacher \& Hayes, 2008). The $95 \%$ bias-corrected bootstrapped confidence intervals $(\mathrm{N}=5000)$ have been estimated (Preacher, Rucker, \& Hayes, 2007). The results in table.5 specify that PSCF has a significant higher indirect impact on guest satisfaction through a guest perceived value $(\beta=-0.35)$, and a bootstrapped estimate of the indirect effect reported for a statistically significant indirect path at $95 \%$ CI [0.07, 0.42]. Henceforth, we accept our Hypothesis 4 . Thus suggesting that guest perceived value partially mediates the association between PSCF and guest satisfaction. The results in Table 6 indicated that the value of beta coefficient of the indirect relationship between PSCF and behavior intention through a guest perceived value $(\beta=-0.25)$ and statistically significant path at $95 \%$ CI $[0.019,0.135]$, supporting our Hypothesis 5 . Then, thus suggesting that guest perceived value partially mediates the association between PSCF and behavior intention. Regarding the mediating effect of guests' perceived value between PSCF and Guests' satisfaction, the findings of this study are consistent with Fountoulaki et al. (2014), as they stated that the way a business provides information for its guests is also important not to develop negative guests' perceived value which may result in dissatisfied and untrusted customers. As Nikbin, Ismail, Marimuthu \& Salarzehi (2012) mentioned in their studies, when the guests' perceived value is damaged due to the disappointments of unhandled booking details and requests thereafter lowered perceived value of the guests cause guest complaints, dissatisfaction, and negative word of mouth. Similar to the findings of Nikbin et al., (2012), the findings of this study is supported by Bastakis et al., (2004) and Buhalis, (2000), as they stated that, when hoteliers offer lower quality service and products to guests, this spoils the guests' experience, decrease guests' perceived value and accordingly decreases guests' satisfaction. Moreover, related with the mediating effect of guests' perceived value between PSCF and guests' behavioral intention, this study is consistent with Goodwin and Ross, (1992) and Spreng et al. (1995), as they mentioned that when any corrective actions or compensation have not been offered to the guests for service failures such as related with unhandled booking details and requests, it results in lower guests' perceived value, and consequently lower guests' satisfaction, and repurchase intention.

Table 5

Effect of PSCF on Guests' Satisfaction through the mediating effect of Guests' perceived value (H4)

\begin{tabular}{ccccccc}
\hline & Direct effect & Indirect effect & LLCI & ULCI & p & Result \\
\hline H4 (PSCF -GPV-GS) & -.7390 & -.3533 & .0724 & .0425 & .0000 & Accepted \\
\hline
\end{tabular}

\section{Table 6}

Effect of PSCF on Guests' Behavioral Intentions through the mediating effect of Guests' perceived value (H5)

\begin{tabular}{ccccccc} 
& Direct effect & Indirect effect & LLCI & ULCI & p & Result \\
\hline H5 (PSCF -GPV-BI) & $\mathbf{- . 7 8 7 2}$ & $\mathbf{- . 2 5 4 1}$ & $\mathbf{. 0 1 9 8}$ & $\mathbf{. 1 3 5 4}$ & $\mathbf{. 0 0 0 0}$ & Accepted \\
\hline
\end{tabular}

\section{Conclusion}

This study aimed to examine whether some conflict issues between accommodation establishments and tour operators/travel agencies are perceived by guests and whether these conflict factors are influencing their satisfaction and behavioral intentions associated with accommodation establishments while examining the mediating role of guests' perceived value. PSCF arose from unsatisfactory relationship between two key tourism stakeholders inform of incorrect representations and promotions of hotels' product and services, inconsistency between requested low prices and expected high-quality product and services from 
hoteliers, mismanagement of bookings and operational mistakes and complaints handling was identified as the barriers to positive guests' outcomes. Therefore, these conflict factors are referred to as the independent construct of the study affecting guests' satisfaction and behavioral intentions as the dependent constructs of the study. The mediation effects obtained indicated that guests' perceived value has mediated the effects of PSCF on guests' satisfaction and behavioral intentions associated with accommodation establishments. Therefore, by boosting guests' perceived value with less PSCF result from cooperative strategies between these major tourism stakeholders, guests will tend to be more satisfied and willing to return the same accommodation establishment at the same time spreading positive recommendations about the place to the family, friends, and colleagues. This will possibly improve the competitive advantage of the hospitality and tourism sector, and the destination itself.

\section{Managerial Implications}

This study has numerous implications for managers that they should consider for their long-term competitiveness and success in the hospitality and tourism industry. Overall, the guest respondents reported unfavorable perceptions of the PSCF associated with accommodation establishments. Therefore, management may maintain the current PSCF associated with their accommodation establishment through a few tips provided by the researchers. First, it is very important to know how managers/owners perceive stakeholder conflict factors because they should see the conflict factors as a triadic problem rather than a dyadic problem. This means that unsatisfactory relationship between the parties is not only ruined the business relationship between the partners, it also ruins the guests' holiday and their response towards this annoyance. Therefore, managers should also consider how each conflict factor might affect guests' perceived value and subsequently guests' satisfaction and their behavioral intentions. And they should concentrate on how to serve best to their guests to be able retained this important stakeholder. Second, as each party is relying on each other for their marketing and service objectives, thus both parties should equally recognize and balance each other's expectations in place of caring only their self-interest and being individualist in this interorganizational system. Also, as both parties are serving the same guests, they should have mutual respect for each other, and they should recognize that careless and disrespectful success affects other parties such as reputation of other partners and even destination itself. Next, good internal and external coordination and communication resolve the negative effect of stakeholder conflict among the parties and on guests' perceived value, satisfaction and behavioral intentions. Both internal coordination and communication among the marketing, reservation and other operational departments, and externally with the partner for managing bookings and booking related requests and problems have paramount importance for PSCF. Then, some PSCF are related to a lack of experiences of employees such as providing misinformation, unmanaged bookings and operational mistakes. Also, lack of empowerment can be another source of conflict issue such as not providing prompt, and effective solutions to guests' problems regardless the source of problem. Moreover, it is necessary to train employees to improve their customer service skills, knowledge of their product and services and communication skills, while it is required for managers to develop their communication and negotiation skills for better business relationships, preventing and resolving problems and conflicts with their partners. Also, managers should know the importance of providing autonomy to their employees which encourages them for a better service and produce the most suitable solutions for their guests. Consequently, it will help to achieve higher guests' perceived value and accordingly higher level of guests' satisfaction and behavioral intentions. Finally, both parties should have a contract consisting of all possible legal concerns in terms of defending themselves from stronger party's opportunistic behaviors. In addition, this agreement should include ethical issues and quality standards regarding hospitality and tourism. Related with ethical and quality standards, there should be standard operating procedures between the parties such as how to share new information, presentation of an accommodation establishment online and /or offline, announcing unexpected repairs or constructions in and outside the property, etc.

\section{Limitations and recommendations for future research}

This study has some limitations that may encourage future research. Firstly, the researchers identified and examined the four sub-dimensions of PSCF's construct for accommodation establishments. Despite the fact that there may be some other subdimensions of PSCF that have to be identified and considered in the conceptual framework of this study. Therefore, future research should seek to identify other factors that may have a significant effect on guests' perceptions of PSCF that have not been identified in this study. Secondly, the guests whose trip were organized by a tour operator/travel agency and staying in a five or four-star accommodation establishments located in Kyrenia, North Cyprus are conducted for this study, therefore the selected sample population is not large enough to generalize the total population and sample size could be a major limitation of the study and future studies can advance this research by choosing a larger sample size as well as expanding the research area (including accommodation establishments with various star-rating, a wider geographic area or country). Lastly, researchers should focus on testing moderating effects in the developed model.

\section{References}

Aljarah, A., \& Ibrahim, B. (2020). The robustness of corporate social responsibility and brand loyalty relation: A meta-Analytic examination. Journal of Promotion Management, 1-35. DOI: 10.1080/10496491.2020.1746464

Alrwashdeh, M., Jahmani, A., Ibrahim, B., \& Aljuhmani, H. Y. (2020). Data to model the effects of perceived telecommunication service quality and value on the degree of user satisfaction and e-WOM among telecommunications users in North Cyprus. Data in brief, 28, 104981.

Ahliya, S. (2010). The importance of hotels and accommodation in promoting tourism. 
Bastakis, C., Buhalis, D. \& Butler, R. (2004). The perception of small and medium sized tourism accommodation providers on the impacts of the tour operators' power in Eastern Mediterranean. Tourism Management, 25, 151-170.

Bolton, R.N. \& Drew, J.H. (1991). A multistage model of customers' assessments of service quality and value. Journal of Consumer Research, 17 (4), 375-384.

Buhalis, D. (2000) Relationships in the distribution channel of tourism: Conflicts between hoteliers and tour operators in the Mediterranean region. International Journal of Hospitality and Tourism Administration, 1, 113-139.

Chen, C.F. (2007), "Experience quality, perceived value, satisfaction and behavioural intentions for heritage tourists", proceedings of the 13th Asia Pacific Management Conference, Melbourne, Australia, 2007, pp.1130-1136.

Churchill, G. A. Jr. (1979). A paradigm for developing better measures of marketing constructs. Journal of Marketing Research, $16(1), 64-73$.

Creswell, J. W. (2012). Qualitative Inquiry and Research Design: Choosing Among Five Approaches. $3^{\text {rd }}$ ed. Thousand Oaks. Sage Publications.

Cox, K. K., Higginbotham, J. B. \& Burton, J. (1976). Applications of focus group interviews in marketing. Journal of Marketing, 40 (1), 77-80.

Cronin, J.J., Brady, M.K. \& Hult, G.J.M. (2000). Assessing the effects of quality, value, and customer satisfaction on consumer behavioural intentions in service environment. Journal of Retailing, 76 (2), 193-218.

Dolores, M.F., Salvador, D.B. \& Lorenza, L. (2012). Determinants of Satisfaction with Holidays and Hospitality in Rural Tourism in Spain: The moderating Effects of Tourists' Previous experience. Cornell Hospitality Quarterly, 54 (3), $294-$ 307.

Douglas, A. \& Lubbe, B. A. (2006). Identifying value conflict between stakeholders in corporate travel management by applying the soft value management model: A survey in South Africa. Tourism Management, 27, 1130-1140.

Edmunds, H. (1999). The focus group research handbook. Lincolnwood, IL. NTC Business Books.

Fountoulaki, P., Leue, M. C. \& Jung, T. (2014). The key factors of relationship quality between tour operators and SME Hotels. EuroChrie, Dubai, United Arab Emirates, 6-9 October 2014.

Frazier, G.L. (1983). International exchange behaviour in marketing channels: A broadened perspective. Journal of Marketing, 47(4), 68-78.

Frazier, G.L. \& Summers, J. (1984). Interfirm influence strategies and their application within distribution channels. Journal of Marketing, 47(3), 43-55.

Freeman, R. E. (1984). Strategic management: a stakeholder approach. Boston, MA. Pitman.

Gaski, J. F. (1984). The Theory of Power and Conflict in Channels of Distribution. Journal of Marketing, 48, 9-29.

Ghada Abd-Alla, M. (2007). Service Quality of Travel Agents: The view point of tourist in Egypt. An International Multidisciplinary Journal of Tourism, 2(1), 63-87.

Gnanapala, W. C. (2016), Stakeholder Conflicts in Tourism: A Study of Hoteliers and Travel Agents in Sri Lanka. In M. Aslam, M. M. Cooper, N. Othman and A. A. Lew (Eds.), Sustainable Tourism in the Global South: communities, environments, and management (pp. 290-307). Cambridge: Cambridge Scholars Publishing

Goodwin, C. \& Ross, I. (1992). Consumer responses to service failures: influence of procedural and interactional fairness perceptions. Journal of Business Research, 25(2), 149-163.

Gupta, A., McDaniel, J.C. \& Herath, S.K. (2005). Quality management in service firms: sustaining structures of total quality service. Managing Service Quality, 15(4), 389-402.

Heynes, S. N., Richard, D., \& Kubany, E.S. (1995). Content validity in psychological assessment: A functional approach to concepts and methods. Psychological Assessment, 7(3), 238- 247.

Hibbard, J. D., Kumar, N., \& Stern, L. W. (2001). Examining the impact of destructive acts in marketing channel relationships. Journal of Marketing Research, 38(1), 45-61.

$\mathrm{Hu}, \mathrm{H}$. , Kandampully, J. \& Juwaheer, T.D. (2009). Relationships and impacts of service quality, perceived value, customer satisfaction, and image: an empirical study. The Service Industries Journal, 29(2), 111-125.

Ibrahim, B., Aljarah, A., \& Ababneh, B. (2020). Do social media marketing activities enhance consumer perception of brands? A meta-analytic examination. Journal of Promotion Management, 26(4), 544-568.

Ibrahim, B., \& Aljarah, A. (2018). Dataset of relationships among social media marketing activities, brand loyalty, revisit intention. Evidence from the hospitality industry in Northern Cyprus. Data in brief, 21, 1823-1828.

Ivanov, S., Stoilova, E. \& Illum, S.F. (2015). Conflicts between accommodation establishments and travel agencies. Tourism and Hospitality Research, 1(15), 54-70.

Johann, M. (2014). The relationship building strategy with partners in tourism market. European Journal of Tourism, Hospitality and Recreation, Special Issue, 95-105.

Karatepe, O. \& Ekiz, E. (2004). The effects of organizational responses to complaints on satisfaction and loyalty: a study of hotel guests in Northern Cyprus. Managing Service Quality: An International Journal, 14(6), 476-486.

Kiran, V., Majumdar, M. \& Kishore, K. (2012). Distribution Channel Conflict and Management. Journal of Business Management and Social Science Research, 1(1), 48-57.

Kourosh, J. (2014). Measurement of Leisure Traveller's Satisfaction: Evidence from North Cyprus Hotels. International Journal of Online Research, 2(2).

Kuo, Y., Wu, C. \& Deng, W. (2009). The relationships among service quality. Perceived value, customer satisfaction and post-purchase intention in mobile value-added service. Computer in Human Behaviour, 25, 887-896. 
Maxham, J. III (2001). Service recovery's influence on consumer satisfaction, positive word-of-mouth, and repurchase intentions. Journal of Business Research, 54(1), 11-24

Mooi, E. A. \& Frambach, R. T. (2009). A stakeholder perspective on buyer-supplier conflict. Journal of Marketing Channels, 16, 291-307.

Moutinho, L. (1987). Consumer behaviour in tourism. European Journal of Marketing, 10(2\1), 5-44.

Mwesiumo, D. \& Halpern, N. (2016). Interfirm conflicts in tourism value chains. Tourism Review, 71(4), $259-271$.

Nadiri, H. (2003). How quality contributes consumer satisfaction: a preliminary study to investigate how hotel attributes quality perceived by customers. In 6th International Conference; Quality management and organizational development, Paris, France. 1-3 October, 2003.

Nadiri, H. \& Hussain, K. (2005). Perceptions of service quality in North Cyprus hotels. International Journal of Contemporary Hospitality Management, 17(6), 469-480.

Nadiri, H., Hussain, K., Haktan, E. \& Erdoğan, Ş. (2008). An investigation on the factors influencing passengers' loyalty in North Cyprus national airline. The TQM Journal, 20(3), 265-280.

Netemeyer, R.G., Durvasula, S. \& Lichtenstein, D.R. (1991). A cross-national assessment of the Reliability and validity of the Cetscale. Journal of Marketing Research, 28(3), 320-327.

Nikbin, D., Ismail, I., Marimuthu, M. \& Salarzehi, H. (2012). The relationship of service failure attributions, service recovery justice and recovery satisfaction in the context of airlines. Scandinavian Journal of Hospitality and Tourism, 12(3), 232254.

Nunnally, J.C. (1978). Psychometric Theory. New York. McGraw-Hill.

Oliver, R. L. \& W. S. Desarbo. (1988). Response determinants in satisfaction judgments. Journal of Consumer Research, 14, 495-504.

Olorunniwo, F., Hsu, M. K. \& Udo, G. J. (2006). Service quality, customer satisfaction, and Behavioural intentions in the service factory. Journal of Service Marketing, 20(1), 59 - 72.

Proctor, T. (2005). Essentials of marketing research. $2^{\text {nd }}$ ed. Harlow: Prentice Hall.

Preacher, K. J., Rucker, D.D., \& Hayes, A. F. (2008). Addressing moderated mediation hypotheses: Multivariate Behavioral Research Methods, 40, 879-891.

Preacher, K. J., \& Hayes, A. F. (2008). Asymptotic and resampling strategies for assessing and comparing indirect effects in multiple mediator models. Behavior Research Methods, 40(3), 879-891.

Ritchie, J.R. \& Goeldner, C. (1994) Travel, tourism and hospitality research: a handbook for managers and researchers, $3^{\text {nd }}$ ed. USA. John Wiley.

Rose, G. M. \& Shoham, A. (2004). International task and emotional conflict with international channels of distribution. Journal of Business Research. 57 (9), 942-950.

Ryu, K., Lee, H., \& Kim, W. G. (2012). The influence of the quality of the physical environment, food, and service on restaurant image, customer perceived value, customer satisfaction, and behavioural intentions. International Journal of Contemporary Hospitality Management, 24(2), 200-223.

Ryu, K., Han, H. \& Kim, T.H. (2008). The relationships among overall quick-casual restaurant image, perceived value, customer satisfaction, and behavioral intentions. International Journal of Hospitality Management, 27(3), 459-69.

Schul, P. L. \& Babakus, E. (1988). An examination of the interfirm power-conflict relationship: The intervening role of the channel decision structure. Journal of Retailing, 64(4), 381-404.

Smith, A., Bolton, R. \& Wagner, J. (1999). A model of customer satisfaction with service encounters involving service failure and recovery. Journal of Marketing Research, 36(3), 356-372.

Spreng, R.A., Harrell, G.D. \& Mackoy, R.D. (1995). Service recovery: impact on satisfaction and Intentions. Journal of Services Marketing, 9(1), 15-23.

Wu, C.H-J. \& Liang, R.-D. (2009). Effect of experiential value on customer satisfaction with service encounters in luxuryhotel restaurants. International Journal of Hospitality Management, 28, 586-93.

Yildirim, C., Oflaç, B.S., \& Yurt, O. (2018). The doer effect of failure and recovery in multi- agent cases: service supply chain perspective. Journal of Service Theory and Practice, 28(3), 274-297.

Zeithaml, V.A. (1988). Consumer perception of price, quality and value; A meansend model and synthesis of evidence. Journal of Marketing, 52(3), 2-22.

Zeithaml, V. A., Berry, L. L. \& Parasuraman, A. (1996). The behavioral consequences of service quality. Journal of Marketing, 60(2), 31-46.

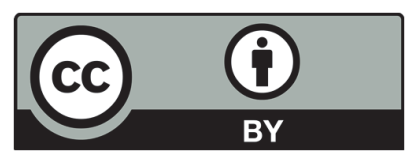

(C) 2020 by the authors; licensee Growing Science, Canada. This is an open access article distributed under the terms and conditions of the Creative Commons Attribution (CC-BY) license (http://creativecommons.org/licenses/by/4.0/). 